BIBLIOGRAPHIE

Gounelle, H. (1941). Bull. Acad. Méd., Paris, 125, 291.

Gounelle, H., Bonfils, S. \& Marnay, C. (1947). Bull. Acad. Méd., Paris, 131, 696.

Gounelle, H., Bonfils, S. \& Marnay, C. (1950). Rec. Inst. nat. Hyg. 4, 403.

Gounelle, H. \& Marche, J. (1943). C. R. Soc. Biol., Paris, 137, 672.

Gounelle, H., Raoul, Y., Vallette, A. \& Marche, J. (I943). C. R. Soc. Biol., Paris, 137, 607.

Gounelle, H. \& Vallette, A. (1944). C. R. Soc. Biol., Paris, 138, 740.

Gounelle, H. \& Vallette, A. (1945a). C. R. Soc. Biol, Paris, 139, 404.

Gounelle, H. \& Vallette, A. (1945b). Pr. méd. 53, 491 .

Gounelle, H., Vallette, A. \& Briand, R. (1945). Bull. Acad. Méd,, Paris, 129, 215.

Gounelle, H., Vallette, A., Raoul, Y. \& Marche, J. (1945). Sem. Hop. Paris, 21, 7.

Gounelle, H. \& Wahnerman, Z. (1945). Bull. Soc. méd. Hóp. Paris, 26 Octobre.

Meunier, P. (1937). Bull. Soc. Chim. biol., Paris, 19, 877.

Raoul, Y., Gounelle, H., Vinet, A. \& Vallette, A. (1941). C. R. Soc. Biol., Paris, r35, I 543.

Vinet, A. (194r). Bull. Soc. Chim. biol., Paris, 23, 354 .

\title{
Ascorbic Acid, Pteroylglutamates, and other Factors in Scorbutic Hydroxyphenyluria
}

By William J. Darby, William J. McGanity, Anne Stockell and Calvin

W. Woodruff (Markle Scholar in Medical Science), Division of Nutrition, Vanderbilt University School of Medicine, Nashville, Tennessee, U.S.A.

That the metabolism of the aromatic amino-acids, tyrosine and phenylalanine, can be altered by changes in ascorbic-acid nutriture is established. Some evidence implicates pteroylglutamic acid as an influence in the metabolism of aromatic amino-acids and of ascorbic acid. It is intended here to review the significant points at which these interrelationships become evident and to try to define the nature of the interrelationship as observed in intact animals.

During the course of a study on the urinary excretion of creatinine by premature infants fed on diets high in protein and low in vitamin C, Levine, Marples \& Gordon (194r) noted the presence in urine of a non-creatinine substance which gave the Jaffé reaction. This was identified by Professor Hans T. Clarke as $p$ hydroxyphenylpyruvic acid. Also present was $p$-hydroxyphenyllactic acid. It was calculated that these premature infants ingested daily approximately $0.5 \mathrm{~g}$ of phenylalanine plus tyrosine/kg of body-weight in the protein of the cow's milk formula which they were fed. The amount of these aromatic metabolites which appeared in the urine was related quantitatively to the protein intake of the infant. When vitamin $\mathrm{C}$ was added to the diet of these premature infants, the tyrosyluria disappeared. The specificity of this effect was attested by the inability of the thenknown members of the vitamin B-complex, either singly or in combination, to alter the tyrosine excretion. The sole exception was that a large dose of liver extract reduced the tyrosyluria in one infant (Levine, Gordon \& Marples, r94I). Fullterm infants fed on similar diets showed no spontaneous defect in the excretion of 
aromatic amino-acids, but tyrosyluria could be induced by the feeding of either phenylalanine or tyrosine in doses of I $\mathrm{g} / \mathrm{kg}$ body-weight. Again, this could be abolished by the administration of ascorbic acid.

Independently, Sealock \& Silberstein (1940) administered large doses of Ltyrosine to scorbutic guinea-pigs during the course of a study on melanin formation. Homogentisic acid, $p$-hydroxyphenylpyruvic and $p$-hydroxyphenyllactic acids appeared in the urine of these animals. The administration of ascorbic acid was followed by the disappearance of these compounds. It was also noted by Sealock (1942) that a variety of metabolites other than vitamin $\mathrm{C}$ could promote this effect in vivo. These studies suggested that a basic relationship existed between ascorbic acid and the aromatic amino-acids.

This view has been strengthened by the production of tyrosyluria by feeding L-tyrosine to scorbutic infants (Morris, Harpur \& Goldbloom, 1950; Woodruff, 1950), human adults (Rogers \& Gardner, 1949), and the scorbutic monkey (Salmon \& May, 1950, 1953), and confirmation of the original observations (Painter \& Zilva, 1947; Woolf \& Edmunds, 1950). The tyrosyluria may be erased by the administration of an active antiscorbutic.

Several fragments of evidence pointed toward a role of folic acid in tyrosine and ascorbic-acid metabolism. In pernicious anaemia in relapse there is an increased blood phenol concentration and an increased phenoluria (Swendseid, Wandruff \& Bethell, 1947a,b). Furthermore, the haematologic level in treated patients with pernicious anaemia has been reported (Dyke, Della Vida \& Delikat, 1942) to decrease during a period of decreased intake of ascorbic acid. Rodney, Swendseid $\&$ Swanson $(1947,1949)$ noted that liver tissue from rats with succinylsulphathiazoleinduced folic-acid deficiency had a decreased capacity for the oxidation of tyrosine. This could be restored in vitro by the addition of pteroylglutamic acid (PGA).

We (Woodruff \& Darby, 1948; Woodruff, Cherrington, Stockell \& Darby, r949) studied the influence of folic acid upon the tyrosine metabolism of the scorbutic guinea-pig in vivo. Guinea-pigs were fed a standard scorbutogenic diet to which L-tyrosine was added at the level of $5 \%$. This diet contained by analysis $0.8 \mu \mathrm{g} / \mathrm{g}$ of folic acid. The expected tyrosyluria resulted. Parenteral or oral administration of massive quantities of PGA abolished the induced tyrosyluria in the scorbutic guinea-pig. Upon cessation of dosing the condition reappeared. There was no clinical evidence of the betterment of scurvy under this regime.

The induction of tyrosyluria by the combination of a vitamin $\mathrm{C}$-free diet and added tyrosine could be prevented by the daily administration of folic acid in large doses (Woodruff et al. 1949). The treated animals died of scurvy in the usual time. Furthermore, treatment with added PGA did not alter the rate of decline of the ascorbic-acid level of the plasma (Fig. I) under this regime (Beam, 1949).

It may be concluded that the tyrosyluria is not a requisite defect for the production of scurvy and, further, that the mechanism of the effect on tyrosine metabolism of large doses of folic acid is not through any ascorbic-acid sparing effect.

It occurred to us that the influence of PGA on tyrosine metabolism might be nonspecific and represent but a readily identifiable manifestation of disturbed amino- 


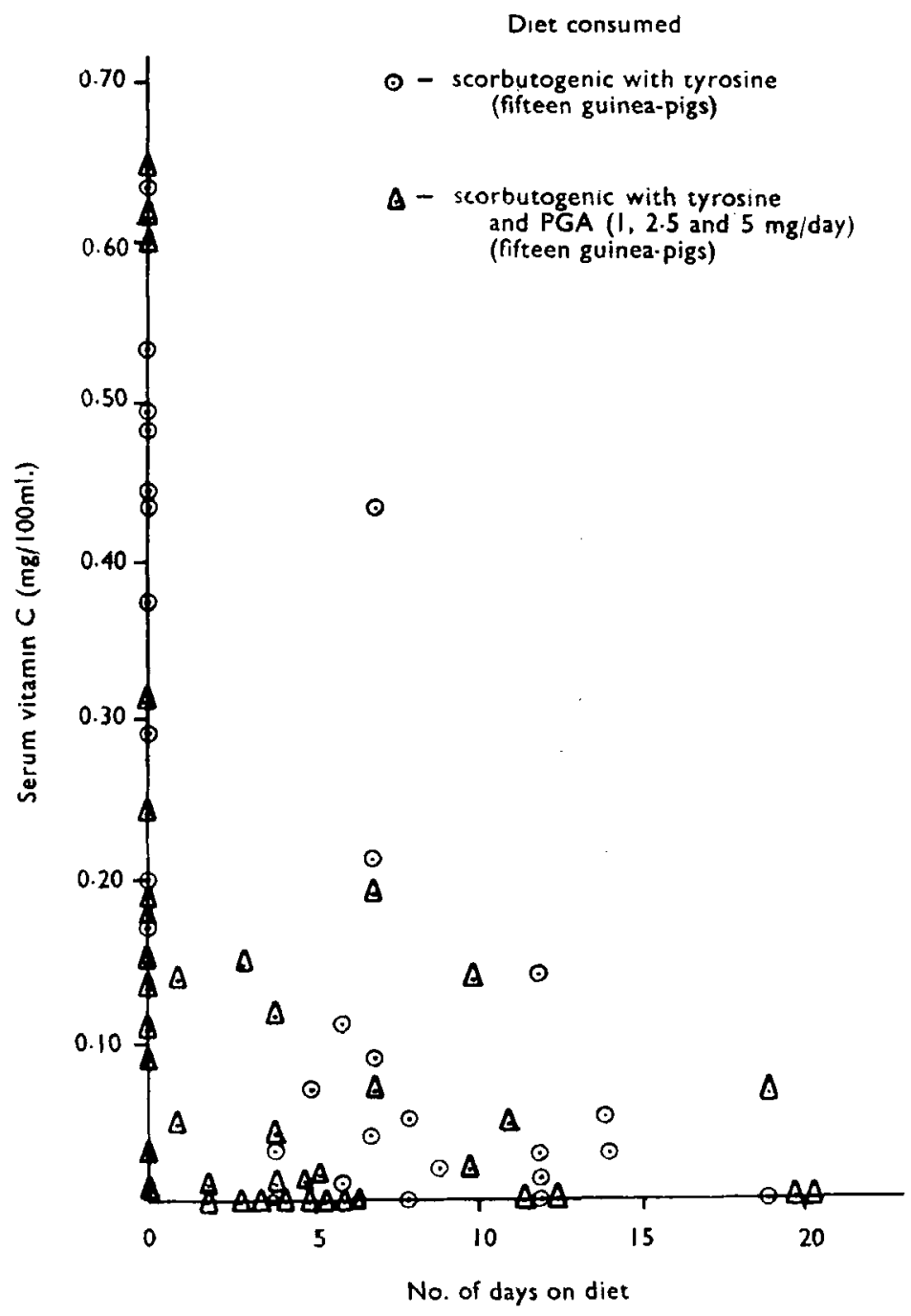

Fig. I. Comparison of the rate of fall of serum ascorbic-acid level of guinea-pigs on a scorbutogenic diet containing tyrosine with and without supplementary vitamin C.

acid metabolism. Hence, the possible effectiveness of pyridoxin under our experimental regime was tested. This vitamin did not influence the tyrosyluria (Fig. 2). Also studied were anti-pernicious-anaemia liver extracts and vitamin $B_{12}$. These were administered parenterally. Neither induced convincing changes in the tyrosyluria. Sealock \& Lepow ( 1948 ) observed a slight decrease in the keto-acid excretion by tyrosine-fed scorbutic guinea-pigs after the injection of liver extract in quantities up to 22 U.S.P. units. Since there was some correlation between the response and unit-potency of the extract, it may be assumed that the effect was due to vitamin $B_{12}$. 


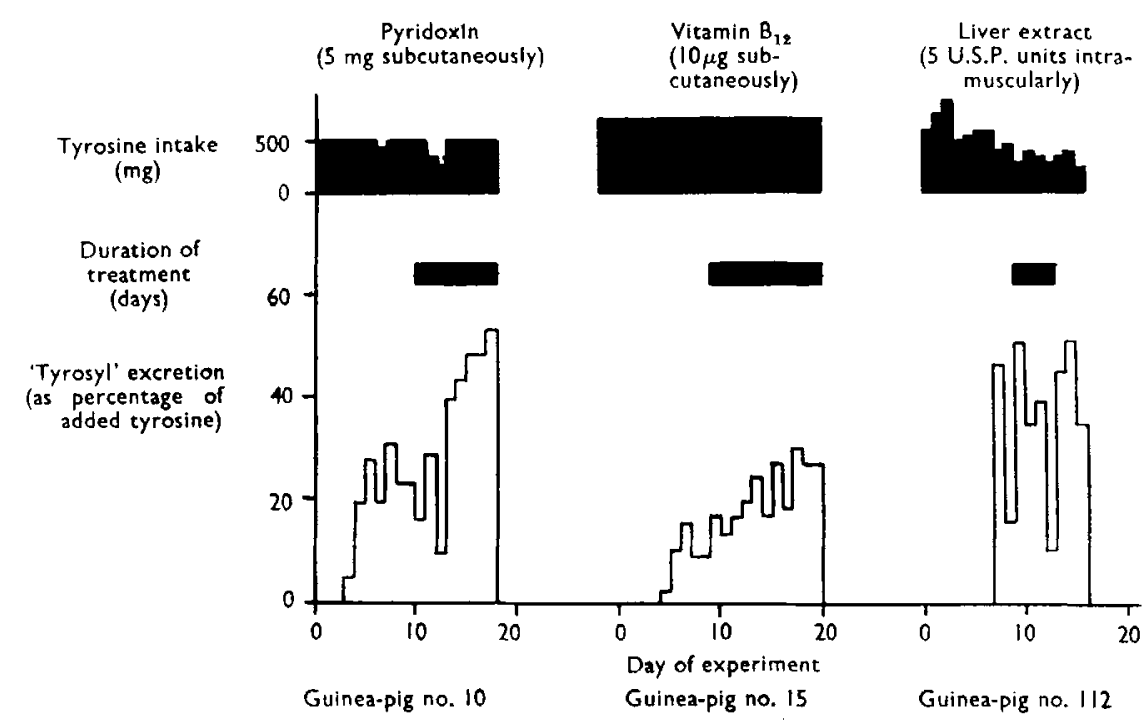

Fig. 2. Illustrative data of the effect of pyridoxin, vitamin $\mathbf{B}_{12}$, and liver extract upon the urinary excretion of tyrosyl by guinea-pigs fed on a scorbutogenic diet containing added tyrosine. All vitamins were given parenterally.

It seems, therefore, that the folic-acid effect is relatively specific among the B-vitamins and that this small transitory activity of an extract containing vitamin $\mathrm{B}_{12}$ represents another example of metabolic interaction with folic acid.

Nichol \& Welch (1950) demonstrated that ascorbic acid enhances the conversion of pteroylglutamic acid into citrovorum factor. This latter substance is more active in some biological tests than is folic acid. That a reduced urinary excretion of citrovorum factor occurs in scurvy and that therapy with ascorbic acid is followed by an increased excretion of this factor has been observed by Gabuzda, Phillips, Schilling \& Davidson (1952) and in our laboratory (Woodruff, unpublished studies). We have tested the effectiveness of citrovorum factor in abolishing the tyrosyluria of guinea-pigs under our conditions of study. Qualitatively (Fig. 3) and quantitatively (Fig. 4) the effect on tyrosyluria of this newer member of the folic-acid group is similar to that of pteroylglutamic acid. Indeed, there is now evidence that three of the naturally occurring pteroylglutamates are effective in this in vivo reaction-pteroylglutamic acid, pteroyltriglutamate, and citrovorum factor. The synthetic diglutamate was not active in the animals in which we have tested it; the heptaglutamate has not been studied. Neither the tested conjugated nor metabolized forms of folic acid exhibit greater activity than pteroylglutamic acid itself.

Scorbutic infants given added tyrosine at a level of some $2.0 \mathrm{~g} / \mathrm{kg}$ body-weight exhibit tyrosyluria similar to that of guinea-pigs. This is alleviated by treatment with vitamin C. Doses of PGA of approximately $2 \cdot 0 \mathrm{mg} / \mathrm{kg} /$ day given intramuscularly failed to correct the abnormal excretion of hydroxyphenyl (Woodruff, I950). Morris et al. (1950) found that doses of approximately $14 \mathrm{mg} P G A / \mathrm{kg} / \mathrm{day}$ were effective in one scorbutic infant but that a dose of $5.7 \mathrm{mg} / \mathrm{kg}$ proved ineffective. 


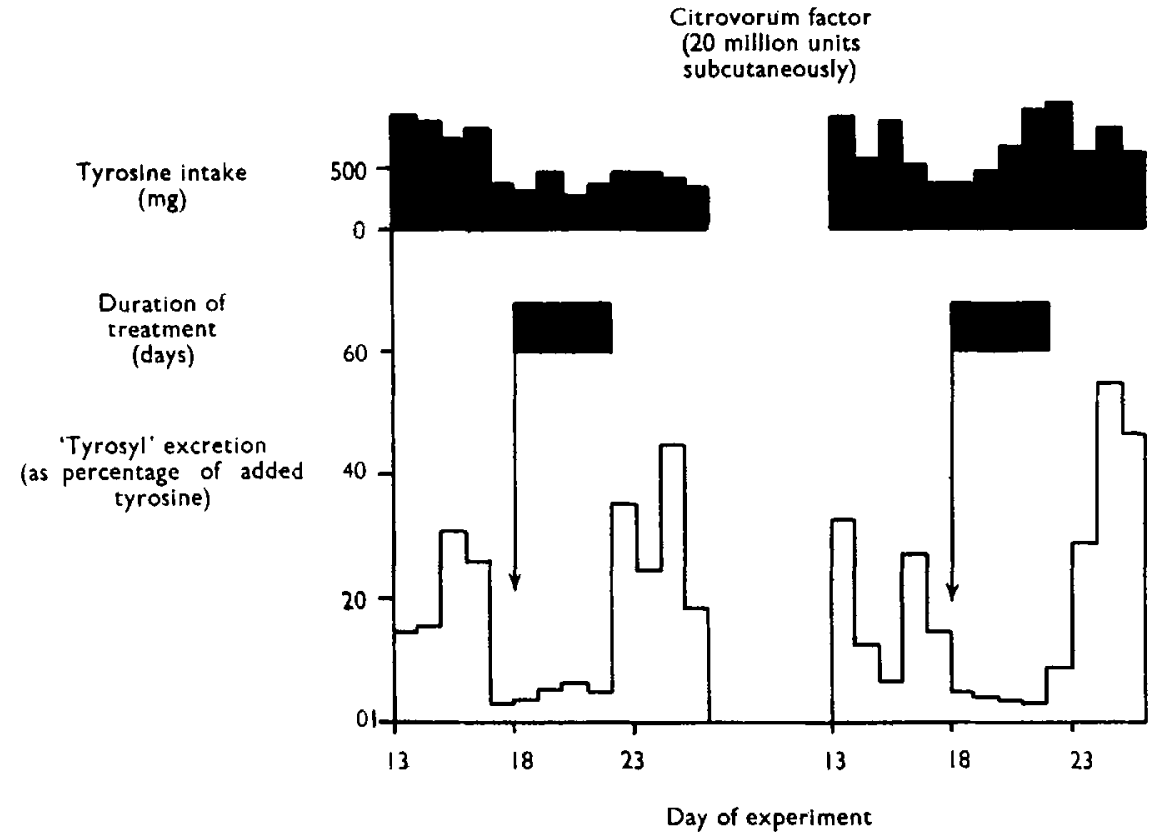

Fig. 3. The effect of citrovorum factor upon tyrosyl excretion by guinea-pigs on a scorbutogenic diet containing added tyrosine. 20 million units of citrovorum factor is the equivalent of $3 \mathrm{mg}$ of the anhydrous free acid (citrovorum factor). The vitamin was given parenterally.

Since infants with megaloblastic anaemia have responded to daily oral doses of PGA as small as 200 or $500 \mu \mathrm{g}$ (Woodruff, Peterson \& Darby, I95 I) it is obvious that the quantity required to counteract the tyrosyluria in scorbutic infants is grossly excessive and unphysiological. Indeed, in guinea-pigs we (Dawson, Woodruff \& Darby, I950) have noted evidences of renal damage within the dosage range which is effective in reducing the hydroxyphenyluria in scorbutic infants.

In studies on premature infants, Nitowsky, Govan \& Gordon (1953) have found that complete abolition of the hydroxyphenyluria was invariably accomplished by ascorbic acid, that it occurred in five of twenty trials with folic acid at varying dosage levels from 2.5 to $30 \mathrm{mg} / \mathrm{kg} /$ day, that folinic acid or citrovorum factor was effective in but one trial in thirteen, and that vitamin $B_{12}$ or liver extract was active in four cases out of eighteen.

Much evidence indicates that tyrosyluria can be altered by hormonal influences. Thus Levine, Barnett, Bierman \& McNamara (I95I) have observed that ACTH in relatively large quantities over a period of at least 7 days will regularly abolish the tyrosyluria of premature infants fed on a high-protein, low ascorbic-acid regime. Cortisone is less effective. Salmon \& May (r953) note that in the scorbutic monkey cortisone has a variable effect on tyrosyluria and that ACTH is without appreciable influence.

These in vivo observations could be supplemented with many related findings. Those cited, however, suffice to indicate that, whereas ascorbic acid is the most 


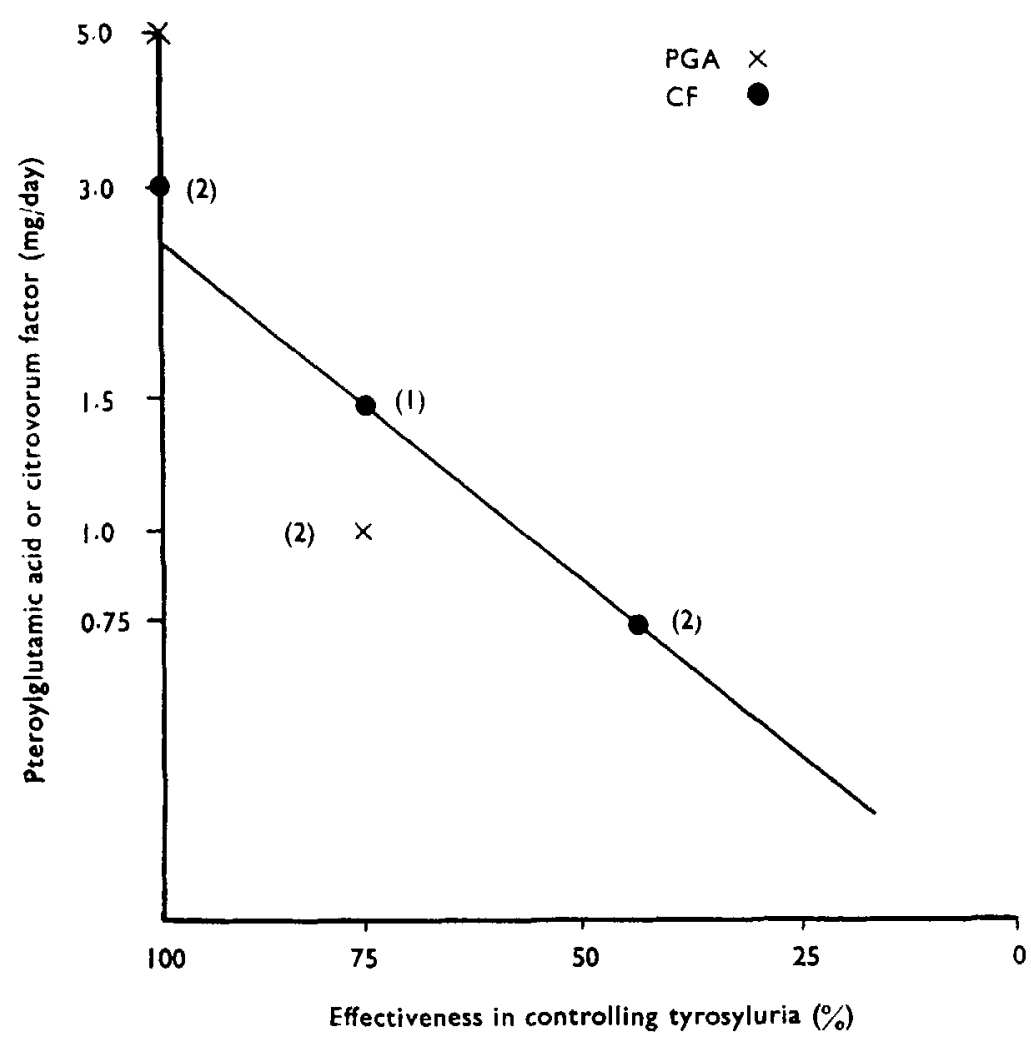

Fig. 4. Comparison of the effectiveness of pteroylglutamic acid and citrovorum factor in the control of tyrosyluria in the guinea-pig. In the limited number of animals presented, it is apparent that the citrovorum factor is not of greatly enhanced potency. Figures in parentheses are the number of animals used.

effective agent in reducing the tyrosyluria in states of low ascorbic-acid nutriture, certain of the new haematopoietic factors have varying activity in excessive doses. The pteroylglutamates are the most notable such factors.

The activity of folic acid does not seem to be mediated through its action on vitamin $\mathrm{C}$, or through replacing a metabolic lack of an active form of folic acid occasioned by the scurvy.

The most plausible explanation of these phenomena is that folic acid is concerned enzymically with one route of metabolism of the aromatic amino-acids and that the provision of excessive quantities of folic acid enables this route to metabolize larger quantities of tyrosine and phenylalanine. Though other explanations may be suggested, this one is supported by the in vitro studies of Rodney et al. (1947, 1949) and of Rienits (1950) to the effect that PGA enhances the oxidation of tyrosine by liver tissue in vitro.

Final clarification of these relationships will occur only when specific (enzymic) functions can be assigned to the nutrients concerned. 
The investigations herein reported from Vanderbilt University were supported in part by grants from the National Vitamin Foundation, the U.S. Public Health Service, and the Nutrition Foundation, Inc.

\title{
REFERENCES
}

Beam, A. S. (1949). A study of serum ascorbic acid in the guinea pig. Thesis submitted to the Graduate Faculty of Vanderbilt University, Nashville, Tennessee.

Dawson, J. R. Jr., Woodruff, C. W. \& Darby, W. J. (I950). Proc. Soc. exp. Biol., N.Y., 73, 646.

Dyke, S. C., Della Vida, B. L. \& Delikat, E. (1942). Lancet, 243, 278.

Gabuzda, G. J. Jr., Phillips, G. B., Schilling, R. F. \& Davidson, C. S. (1952). F. clin. Invest. 31, 756.

Levine, S. Z., Barnett, H. L., Bierman, C. W. \& McNamara, H. (1951). Science, rr3, 3 II.

Levine, S. Z., Gordon, H. H. \& Marples, E. (194I). F. clin. Invest. 20, 209.

Levine, S. Z., Marples, E. \& Gordon, H. H. (194I). F. clin. Invest. 20, 199.

Morris, J. E., Harpur, E. R. \& Goldbloom, A. (1950). F. clin. Invest. 29, 325.

Nichol, C. A. \& Welch, A. D. (1950). Proc. Soc. $\exp$. Biol., N.Y., 74, 52.

Nitowsky, H. M., Govan, C. D. Jr. \& Gordon, H. H. (1953). Amer. F. Dis. Child. 85, 462.

Painter, H. A. \& Zilva, S. S. (1947). Biochem. F. 41, 5 I I.

Rienits, K. G. (1950). F. biol. Chem. 182, I r.

Rodney, G., Swendseid, M. E. \& Swanson, A. L. (1947). F. biol. Chem. 168, 395.

Rodney, G., Swendseid, M. E. \& Swanson, A. L. (1949). F. biol. Chem. 179, 19.

Rogers, W. F. Jr. \& Gardner, F. (1949), F. clin. Invest. 28, 806.

Salmon, R. J. \& May, C. D. (1950). F. Lab. clin. med. 36, $59 \mathrm{I}$.

Salmon, R. J. \& May, C. D. (r953). F. Lab. clin. Med. 4r, 376.

Sealock, R. R. (1942). $f$. biol. Chem. 146, 503.

Sealock, R. R. \& Lepow, J. P. (1948). F. biol. Chem. 174, 763.

Sealock, R. R. \& Silberstein, H. E. (1940). $\mathcal{F}$. biol. Chem. 135, 25 r.

Swendseid, M. E., Wandruff, B. \& Bethell, F. H. (1947a). F. Lab. clin. Med. 32, I242.

Swendseid, M. E., Wandruff, B. \& Bethell, F. H. (1947b). F. Lab. clin. Med. 32, 1248.

Woodruff, C. W. (1950). F. Lab. clin. Med. 36, 640 .

Woodruff, C. W., Cherrington, M. E., Stockell, A. K. \& Darby, W. J. (1949). F. biol. Chem. 178, 86r. Woodruff, C. W. \& Darby, W. J. (r948). F. biol. Chem. 172, 85 I.

Woodruff, C. W., Peterson, J. C. \& Darby, W. J. (1951). Proc. Soc. exp. Biol., N.Y., 77, 16.

Woolf, L. I. \& Edmunds, M. E. (1950). Biochem. F. 47, 630.

\section{Synthesis of L-Ascorbic Acid in Plants and Animals}

\author{
By F. A. IsHerwoon, Low Temperature Station for Research in Biochemistry and \\ Biophysics, University of Cambridge and Department of Scientific and Industrial \\ Research
}

The chemical synthesis of L-ascorbic acid from D-galactose, by Haworth, Hirst and co-workers in 1932 , stimulated speculation as to whether the biological synthesis of L-ascorbic acid proceeds along similar lines (Haworth \& Hirst, 1933). The common occurrence of sugars in both plants and animals, and the fact that $\mathrm{L}-$ ascorbic acid is closely related to a sugar, L-gulose, tended to support this idea. Two 